\title{
Covid -19 Pandemic: Issues and Challenges Among Women Entrepreneurs in Malaysia.
}

Nurjanah Mahat, Ida Rahayu Binti Mahat, Mimi Sofiah Ahmad Mustafa

To Link this Article: http://dx.doi.org/10.6007/IJARBSS/v11-i6/10114

DOI:10.6007/IJARBSS/v11-i6/10114

Received: 07 April 2021, Revised: 10 May 2021, Accepted: 27 May 2021

Published Online: 11 June 2021

In-Text Citation: (Mahat et al., 2021)

To Cite this Article: Mahat, N., Mahat, I. R. B., \& Mustafa, M. S. A. (2021). Covid -19 Pandemic: Issues and Challenges Among Women Entrepreneurs in Malaysia. International Journal of Academic Research in Business and Social Sciences, 11(6), 231-239.

Copyright: (c) 2021 The Author(s)

Published by Human Resource Management Academic Research Society (www.hrmars.com)

This article is published under the Creative Commons Attribution (CC BY 4.0) license. Anyone may reproduce, distribute, translate and create derivative works of this article (for both commercial and non-commercial purposes), subject to full attribution to the original publication and authors. The full terms of this license may be seen at: http://creativecommons.org/licences/by/4.0/legalcode

Vol. 11, No. 6, 2021, Pg. 231 - 239

Full Terms \& Conditions of access and use can be found at http://hrmars.com/index.php/pages/detail/publication-ethics 


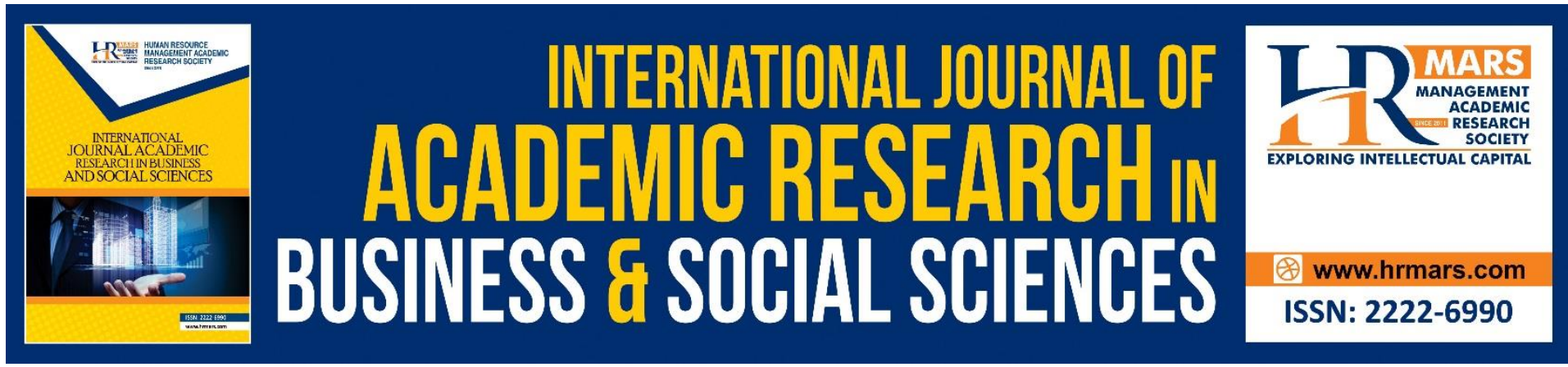

\title{
Covid -19 Pandemic: Issues and Challenges Among Women Entrepreneurs in Malaysia.
}

\author{
Nurjanah Mahat \\ Language Department, Kolej Mara Banting, Selangor, Malaysia. \\ Ida Rahayu Binti Mahat \\ Law Department, Universiti Teknologi Mara, Melaka Branch, Malaysia. \\ Mimi Sofiah Ahmad Mustafa \\ Law Department, Universiti Teknologi Mara, Melaka Branch, Malaysia.
}

\begin{abstract}
Studies on women entrepreneurship have witnessed a rapid growth over the past 30 years. Women's entrepreneurship is a district that needs specific research attention within the wake of the COVID 19 pandemic, as many are affected financially and emotionally. Many are reported seeking help and switching businesses literally to overcome the challenges. Women in small medium enterprises (SME) are still struggling to make ends meet even though numerous numbers of support are given by the government. By statistics, women are also keen to remain with entrepreneurship in informal sectors. Historically, women in general received perception of gender bias, being critically suppressed, and remained the symbol of subordinates. Thus, this conceptual paper intends to investigate and determine the issues and challenges among women entrepreneurs in the small medium enterprises (SME) and from the informal sectors of the economy in the midst of pandemic Covid-19. This paper employs doctrinal study by collecting primary and secondary data from books, journals, legislations, and manuscripts. Data collection were analyzed by using content analysis techniques with the aim to analyze the impact of the pandemic on women entrepreneurs holistically.
\end{abstract}

Keywords: COVID 19-Issues and Challenges-Women, Entrepreneurs-Small Medium, Enterprises-Informal Sectors

\section{Introduction}

\section{Covid-19 and Impact on Women Entrepreneurs}

The Covid -19 has been viewed as the unpredictable event of 2020 and has caused severe impact to business operations and supply chains. Many businesses around the globe were closed and interrupted (Lim, 2020; World Trade Organization, 2020). The COVID-19 pandemic has posed an unusual challenge for all economic sectors. As reported, small and medium enterprises are at the center of the COVID-19 crisis (Organization for Economic Cooperation and Development (OECD). Besides men, female entrepreneurs are the ones who have been most challenged, as they have already been through current hurdles, like limited access to 
business ventures, lack of networks and expertise, and gender biases (International Trade Centre, 2020; Villaseca et al., 2020). Other important issues are, for example, the small size and the young age of the women firms (Chmura, 2020), the lack of business funds and the full reliance on informal financing (Orser, 2020). To add, no support from the business alliance during the pandemic period (Henry, 2020). By paying attention to these gendered problems, policymakers need to financially support women on a priority basis. (Jaim, 2020). Based on the official statistics analysis in 2005-2020, it is found that an adverse trend shows a decrease in business startups and business closures.

From the library search, it is found that many countries are taking actions (International Trade Centre, 2020) in funding the small and medium-sized enterprises (SMEs) and the entrepreneurs from the informal sectors (Williams, 2016) to lessen the economic impact of the COVID-19 disruption (Weng et al., 2020). The immediate effect of the crisis had caused mass layoffs and closures of business up to $43 \%$ and the employment had fallen by 40\%. (Bartik et al., 2020). According to the AmBank Group chief economist Anthony Dass, tourism and travel industries, manufacturing, construction, mining, and agriculture are mostly affected, with many employees being ceased and some have to take on unpaid leaves (Murugiah, 2020 as cited in Ain Umaira, 2020).

The hit and impact of the pandemic strikes in Malaysia is similar to the rest of the countries in the world. Newspapers and social media are keeping up with the threat and updates on the impact to the SME sectors and all kinds of business entirely. The President of Association of Bumiputera Women in Business and Profession, or better known as Peniagawati, Datuk Azlin Ahmad Shaharbi reported that more than 190,000 women entrepreneurs were greatly affected by the pandemic (Harian, 2020). Furthermore, Penang State Social Development Committee Chairman, Chong Eng, said women entrepreneurs must be given necessary training and mentoring to face the economic challenges during the Covid19 pandemic. (SME Official website).

\section{Issues and Challenges Faced by Women Entrepreneurs Gender Bias in Business Funding}

From the literature, potential gender bias is identified both on the supply and demand side of financing. Women entrepreneurs face difficulties in finance access, lack of networks and gendered priorities. Since Covid-19 has posed a big threat to women entrepreneurs, gender policies are suggested to reduce the gender gap in order to keep women entrepreneurs survive (Villaseca et al, 2020). In one research that conducted an observational and experimental study found that catering female owners received significantly less funding in some male-dominated industries as compared to other female-led catering businesses in female-dominated industries (Kanze et al, 2020).

Besides, some research have highlighted that gender bias against women entrepreneurs happens in bank fund lending applications (Fay and Williams, 1993; Lakovleva et al. 2013; Becker-Blease and Sohl, 2007; Marlow and Swail, 2014). Many other researchers question whether this issue really exists. The researchers debated on the issue of gender prejudice in lending organizations. The female entrepreneurs involved in one of the studies revealed that they did actually face discriminatory treatment by the financial institutions (Fabowale et al., 1995; O'Gorman and Terjesen, 2006; Eddleston et al., 2014). Thus, it can be seen that gender roles, which reflect entrepreneurs' psychological traits and behavior styles from a gender perspective, have attracted researchers' attentions in discussing about gender bias in these past few years. Gender roles among female entrepreneurs greatly affect the 
entrepreneurs' decisions to choose external funding and their social capital, which in turn is a significant but not the only factor that influences their choice of external financing (Wang et al., 2020).

\section{Perceptions about Women Entrepreneurs}

Earlier, the role of women was confined to nurturing the family as homemakers, but this perception has transformed tremendously in adapting to the new era. Barriers to women entrepreneurship are numerous and they include: lack of education, experience, and training opportunities; spatial mobility and lack of family support; lack of institutional support; lack of entrepreneurial management; and problems in acquiring financial resources (Raghuvanshi et al., 2017).

According to Cowing et al, women entrepreneurs are perceived as not ' $f$ it' in the discipline as compared to the male entrepreneurs (Ahl, 2006) whilst standard gendered barriers hinder their ability to get important entrepreneurial resources (Marlow and McAdam, 2013). Although contrary to the results of another research which revealed women entrepreneurs often face difficulty to get fundings (McAdam, 2012), women entrepreneurs are linked with a greater risk of aversion (Marlow and Swail, 2014) as the funders provide more traditional lending applications. This action is deemed as a reduction of gender bias in unfair funding decisions.

\section{Crisis Management}

Salamzadeh \& Dana further stated that crisis management becomes a vital issue that must be handled well as it is among the big challenges faced by the novice entrepreneurs (2020). In fact, all other sectors should also utilize appropriate methods of risk measurement and should take 'Black Swans' into account to incorporate a more accurate probability of unexpected events. (Gunay \& Kurtulmuş, 2021). Findings from a research highlighted that participating firms dealt more with internal stakeholders compared to the external stakeholders. The interventions practised by small firms involve flexible human resource (HR) practices, cost reduction, enhancing customer relations, and using government support schemes. These approaches are practical only for a short period of time; thus, business companies must be more creative in venturing more business opportunities and survive for a longer period of time (Alves et al., 2020). According to Nicola et al (2020), relief measures need to be applied and refined for those that may fall through the cracks. Longer-period of planning is needed to re-balance and re-energize the economy.

Based on past observations, after the Wenchuan earthquake in New Beichuan, China, male entrepreneurs were more likely able to sustain their businesses as compared to female entrepreneurs (Li et.al, 2019). After Hurricane Katrina hit, businesses led by women were more likely to face closures than men-led businesses (Marshall et al.,2015). By referring to these natural disasters' issues, a study of the application process for federal disaster loans following Hurricane Katrina was referred. According to a study done by Josephson and Marshall in 2016, it was revealed that women owners received lower amounts when they applied for disaster loans (Manolova, 2019). Thus, it is shown that crisis management is important for entrepreneurs especially for the women entrepreneurs. 


\section{Existing Support from the Government}

Malaysia Prime Minister had announced the RM250 billion PRIHATIN Package on March 27, 2020 to support micro, small, and medium-sized enterprises. The Ministry also received support from the insurance sectors, both conventional and Islamic insurance (Sunil, 2020).

Moreover, with the recent announcement by the government, women entrepreneurs will get more benefits from various programs planned under the 2021 Budget which focuses on saving the economy following the great impact of Covid-19 pandemic. According to Datuk Azlin Ahmad Shaharbi, president of the Association of Bumiputera Women in Business and Profession (Peniagawati), apart from the RM50 million provided via Ar-Rahnu BizNita and RM95 million under Tekun Nasional, Majlis Amanah Rakyat and Agrobank, there were other aids offered to empower women entrepreneurs in Malaysia (Povera, 2020).

Among other initiatives to mitigate the impact of COVID-19 are announced as PRIHATIN Economic Stimulus Package, declarations by Bank Negara Malaysia (BNM), relief measures for SMEs affected by COVID-19, additional measures to support SMEs affected by the COVID-19 outbreak, eBazar Ramadan and program Scale-Up Alumni TUBE (Official website of SME Corporation Malaysia).

\section{Legitimacy}

In Malaysia, the Covid-19 (Temporary Measures) Act 2020 has been enacted to assist affected people especially the ones involved in the economic sector. A few countries have also constructed new Acts, Rules and Regulations or amended the existing ones, to combat this big issue (Khoo,2020). For example, India has its two existing laws, the Epidemic Diseases Act 1897 and the Disaster Management Act 2005 as these are outdated laws (Banerjee, 2020).

Research proposed measures could be utilized by policymakers in assisting entrepreneurs to face the challenges during this pandemic. Among the suggestions was that policy measures should not only provide first aid to startups by alleviating the pressure caused by constrained cash flow but should also involve long-term measures embedded in and supported by the wider entrepreneurial ecosystem to ensure rapid recovery and growth (Kuckertz et al., 2020). With regards to the ongoing impact of the COVID-19 pandemic in the domain of entrepreneurship, research-based evidence and associated insights focused on three perspectives (i.e., business planning, frugality, and emotional support) regarding entrepreneurial action under an exogenous shock (Giones et al., 2020). It is proposed that it is an exogenous shock because the Covid-19 pandemic is so unexpected and unpredictable that has been giving mass impact on the lives of all the people universally.

The existing public policy toward SME should be revised and formed according to the current situation and post pandemic effect (Abugu \& Abuja, 2020). Lawmakers must create relevant policies to assist the entrepreneurs to survive in this critical situation (Salamzadeh \& Dana, 2020).

\section{Women Entrepreneurs from the Informal Economy}

Entrepreneurs that are involved in informal sectors were considered informal entrepreneurs if their firm or employer was profit-oriented; unregistered with the Companies Commission of Malaysia (CCM) or professional bodies or local government; and had less than ten workers (Khazanah Research Institute Discussion Paper 2020). Women's choice to embark into the informal economy is confirmed by many scholars. This distinction is even more problematic in the context of women entrepreneurship, whose entrepreneurial choices are shaped by social institutions and cultural norms (Karki et al., 2020). Thus, marginalized entrepreneurs 
such as self-employed women and women-owned businesses require targeted support (Dy \& Jayawarna, 2020).

Women entrepreneurs were seen to be dominant in the informal sector; however, statistics in 2017 showed that 839,200 workers or $61.5 \%$ of this workforce were male and only $38.5 \%$ were women. According to the Department of Statistics, the involvement of women in the informal sector experienced an increase last year with 548,900 (43.7 per cent) compared with 38.7 per cent in 2017. Thus, it shows less popularity of engagement in the informal sector by women (Khazanah Research Institute Discussion Paper 2020). Yet, a study shows that the services sector was a dominant industry for both male and female workers in the informal sector. Between 2011 and 2017, the average share of workers employed by services for male workers was $53.4 \%$; while the average share was $73.2 \%$ for female workers. (Khazanah Research Institute Discussion Paper, 2020).

In comparison to other countries, a conducted study in Tanzania found that there are long and complex procedures that disrupt business registration of women SMEs. The complex procedures involve name clearance application process, declaration of compliance application process, certificate of incorporation application process, taxpayer identification number (TIN) application process, business license and VAT certificate application process. All these ineffective procedures are so complex that they lead to dissuasion of the registration of women SMEs in Tanzania (Kaale, 2020).

Issues of non-registration, nonpaying taxes and avoiding formal working contracts seem unimportant and insignificant to them. Women remain the contributors and players in the informal economy (Karki et al., 2020). Refusal to register the business becomes the main problem in gaining financial aid from the government. However, a study reveals that although most of the informal businesses operate 'illegally', this is more due to the unclear registration rule than the mark of a deliberate intention to evade the economic regulations and it is a matter of "to register or not" (Cling et al., 2012).

Other than business registration issues, a study shows that some operation instruments have not been effective in promoting innovation in SMEs because of weak policy mix and inconsistency, weak capacity of government to adjust policy instruments to target systemic innovation deficits, and institutional disarticulation within government departments (John et al., 2021). Thus, many of the women entrepreneurs prefer to stay in the informal economy.

To relate all the above issues occurring in Tanzania with the situation in Malaysia, where registration of business is concerned, the procedure is much easier and simpler as it could be done online apart from being present at the CCM office to register by filling the forms physically. However, it could be a problem if the woman entrepreneur has low information technology knowledge or transportation issues. Others may include the access to internet issues at the location where they live. Access to internet can be contributory to other lack of information regarding entrepreneurship that the government or other parties may want to disseminate to these women-led informal businesses.

\section{Conclusion and Recommendations}

In our on-going study, we found that women entrepreneurs from small and medium-sized businesses and from the informal sectors around the globe are greatly affected because of the Covid-19 pandemic. Unlike men entrepreneurs, women entrepreneurs faced many issues and challenges such as difficulty to obtain business funds, limited access to network 
and expertise support. Thus, assistance and support should continuously be given to them in ensuring that women entrepreneurs can survive and sustain their business before, during and after the pandemic hit.

The percentage of women in the informal sector is not just referring to women who do not have education at the tertiary level, but also women who have tertiary education qualification. Nowadays, women are looking for an alternative; to work with flexible conditions where they can play their role not only as workers but also as mothers. The development is accelerating and becomes an alternative for women to generate income and build the resilience of their livelihood. Hence, the initiative of the government in strengthening the involvement of women in business is timely. Indeed, it shows the commitment and determination of the government to ensure no one is left out in the labor market, including the informal sector.

Therefore, with the current economic challenges, the percentage of women with tertiary education qualification is also among the contributors to the informal sector workforce. The digital era has given women a career in the gig economy. With their ability, expertise, and skills in the production of food, creative products and fashion, it creates an opportunity for online businesses.

As to date, there are many governments' supports given to the entrepreneurs namely, business funds, online and offline business training and business consultations. Other than facilities and incentives given by the authorities, the findings of this study show that the women entrepreneurs should be taught with crisis management skills. This is an important skill that women entrepreneurs should be better equipped with in order to survive and know how to respond with business crises. For women entrepreneurs from the informal sectors, as they are unregistered with CCM and local authorities, exposure on the benefits in getting the business to be formalized must be raised. Among the setbacks for not getting the business to be formal is that they will always face difficulty to get business funds and training. For future research, the authors hope that studies on empowerment of women entrepreneurs can focus more on bringing them into the formal sector despite the challenges of the current pandemic.

Local authorities in Malaysia are very serious about raising the number of registered women entrepreneurs (SME Official website). Therefore, formal entrepreneurship undeniably provides a significant contribution to the GDP of the country.

\section{Corresponding Authors}

Nurjanah Mahat

Language Department, Kolej MARA Banting, Malaysia

Email: nurjanah@mara.gov.my

\section{References}

Abugu, I., \& Abuja, T. H. H. (2020). SME: Issues, challenges \& prospects. In Abuja International Conference on Financial System Strategy.

Alias, (2020). Covid 19-Lebih 190000 usahawan wanita.

https://www.bharian.com.my/bisnes/lain-lain/2020/04/673623/covid-19-lebih190000-usahawan-wanita-terjejas

Bartik, A. W., Bertrand, M., Cullen, Z., Glaeser, E. L., Luca, M., \& Stanton, C. (2020). The impact of COVID-19 on small business outcomes and expectations. Proceedings of the National Academy of Sciences, 117(30), 17656-17666. 
Banerjee, B. (2020). COVID-19 Containment: Legal Framework for Regulatory Approach. Journal of Comprehensive Health, 8(2), 66-73.

Chmura, M. (2020). Pandemic Impacts Entrepreneuring Women at Work and Home. Babson College. Retrieved from https://entrepreneurship.babson.edu/pandemic-impactsentrepreneuringwomen-at-work-and-home/.

Cling, J. P., Razafindrakoto, M., \& Roubaud, F. (2012) To be or not to be registered? Explanatory factors behind formalizing non-farm household businesses in Vietnam, Journal of the Asia Pacific Economy, 17:4, 632-652, DOI:

10.1080/13547860.2012.724553 Retrieved from https://dx.doi.org/10.1080/13547860.2012.724553

Dy, A., \& Jayawarna, D. (2020). Bios, mythoi and women entrepreneurs: A Wynterian analysis of the intersectional impacts of the COVID-19 pandemic on self-employed women and women-owned businesses. International Small Business Journal, 38(5), 391-403.

Gunay, S., \& Kurtulmuş, B. E. (2021). COVID-19 social distancing and the US service sector: What do we learn?. Research in International Business and Finance, 56, 101361.

Giones, F., Brem, A., Pollack, J. M., Michaelis, T. L., Klyver, K., \& Brinckmann, J. (2020). Revising entrepreneurial action in response to exogenous shocks: Considering the COVID-19 pandemic. Journal of Business Venturing Insights, 14, e00186.

Henry, C. (2020). Women enterprise policy and COVID-19: Towards a gender sensitive response. Retrieved from https://sites.telfer.uottawa.ca/were/files/2020/06/OECDWebinar-WomenEntrepreneurship-Policy-and-COVID-19_Summary-Report.pdf

Ishak, (2020). Peniagawati hargai nasib usahawan. Retrieved from

https://www.bharian.com.my/wanita/lain-lain/2020/11/752556/belanjawan-2021peniagawati-hargai-peka-nasib

usahawanhttps://www.smecorp.gov.my/index.php/en/resources/2015-12-21-10-5522/news/4268-mentoring-programme-equips-entrepreneurs-with-skills-to-excel-inbusiness-world

Jaim, J. (2020). Exist or exit? Women business-owners in Bangladesh during COVID-19. Gender, Work \& Organization.

Kaale, G. (2020). The influence of Business Registration on Profit and Sales of Women SMEs in Tanzania (Doctoral dissertation, Mzumbe University).

Kanze, D. A, Conley, M. A, Okimoto, T. G., Philips, D. .J \& Merluzzi, J. E. (2020).Evidence that investors penalize female founders for lack of industry fit.Science Advances (United Kingdom) (6)(48).

Karki, S., Xheneti, M., \& Madden, A. (2020). To Formalize or Not to Formalize: Women Entrepreneurs' Sensemaking of Business Registration in the Context of Nepal. Journal of Business Ethics, 1-22.

Kuckertz, A., Brändle, L., Gaudig, A., Hinderer, S., Reyes, C. A. M., Prochotta, A., \& Berger, E. S. (2020). Startups in times of crisis-A rapid response to the COVID-19 pandemic. Journal of Business Venturing Insights, 13, e00169.

Lim, N. (2020). COVID-19 Implications for Contracts under Singapore and English Law. Sing. Comp. L. Rev., 119.

Nicola, M., Alsafi, Z., Sohrabi, C., Kerwan, A., Al-Jabir, A., losifidis, C.,\& Agha, R. (2020). The socio-economic implications of the coronavirus pandemic (COVID-19): A review. International journal of surgery (London, England), 78, 185. 
Orser, B. (2020). Women enterprise policy and COVID-19: Towards a gender sensitive response. Retrieved from https://sites.telfer.uottawa.ca/were/files/2020/06/OECDWebinar-WomenEntrepr neurship-Policy-and-COVID-19_Summary-Report.pdf

Ouma-Mugabe, Chan \& Marais. (2021). "A Critical Review of Policy Instruments for Promoting Innovation in Manufacturing Small and Medium Enterprises (SMEs) in South Africa," Springer Books, in: Dosso \& Amadi-Echendu (ed.), Entrepreneurship, Technology Commercialisation, and Innovation Policy in Africa, pages 237-258, Springer.

Povera, A. (2020). 2021 Budget: Entrepreneurs get Help. Retrieved from https://www.nst.com.my/news/nation/2020/11/643754/2021-budgetentrepreneurs-get-help

Raghuvanshi, J., Agrawal, R., \& Ghosh, P. K. (2017). Analysis of barriers to women entrepreneurship: The DEMATEL approach. The Journal of Entrepreneurship, 26(2), 220-238.

Saleh, A. S., \& Ndubisi, N. O. (2006). An evaluation of SME development in Malaysia. International review of business research papers, 2(1), 1-14.

Tumin. (2020). Unregistered and "Invisible": Workers in Malaysia's Informal Sector. Kuala Lumpur: Khazanah Research Institute. License: Creative Commons Attribution CC BY 3.0

Villaseca, D., Navio-Marco, J., \& Gimeno, R. (2020). Money for female entrepreneurs does not grow on trees: start-ups financing implications in times of Covid-19. Journal of Entrepreneurship in Emerging Economies (Spain).

Wang, S. S., Goh, J. R., Sornette, D., Wang, H., \& Yang, E. Y. (2020). Government Support for SMEs in Response to COVID-19: Theoretical Model Using Wang Transform (No. 20-59). Swiss Finance Institute.

Women have a vital role to play in post-pandemic recovery. (2020). International Trade Centre. Retrieved from https://www.intracen.org/news/Women-have-a-vital-role-toplay-in-post-pandemic-recovery/ 